\title{
Sumari
}

Papers. Revista de Sociologia

Juliol-setembre 2012, vol. 97, núm. 3, p. 505-714, ISSN 2013-9004

Les paraules clau són en llenguatge lliure

http://papers.uab.cat

509 Notificació de retirada d'article per apropiació d'autoria i invenció de dades

511-520 Oso, Laura; Ribas-Mateos, Natalia (Universidad de A Coruña)

De la sorpresa a la incertidumbre: abriendo etapas en el estudio de la temática sobre género y migración en el contexto español. Papers, 2012, vol. 97, núm. 3, p. 511-520.

\section{Artícles monogràfic}

Nuevos retos en los estudios de género y migración en España

523-540 Juliano Corregido, Dolores (Universidad de Barcelona)

Género y trayectorias migratorias en época de crisis. Papers, 2012, vol. 97, núm. 3, p. 523-540.

Palabras clave: migraciones; mujeres inmigrantes; crisis económica; discriminación; xenofobia; estrategias de supervivencia; política de inmigración; redes de inmigración; victimización.

541-568 PEDONE, Claudia (Institut d'Infancia i Món Urbà); AGRELA RoMERO, Belén (Universidad de Jaén); GIL ArAUjO, Sandra (Universidad de Buenos Aires) Políticas públicas, migración y familia. Una mirada desde el género. Papers, 2012, vol. 97, núm. 3, p. 541-568.

Palabras clave: inmigrantes latinoamericanos; reagrupamiento familiar; estratificación cívica; migración familiar; política migratoria; España. 
569-590 Gregorio GiL, Carmen (Universidad de Granada)

Tensiones conceptuales en la relación entre género y migraciones. Reflexiones desde la etnografía y la crítica feminista. Papers, 2012, vol. 97, núm. 3, p. 569-590.

Palabras clave: maternidad transnacional; cuidados; mujer inmigrante; cambio social; diferencia cultural; raza; etnicidad.

591-612 SÁIz López, Amelia (Universitat Autònoma de Barcelona)

Mujeres chinas en España. El capital social y su impacto en las estrategias productivas y reproductivas. Papers, 2012, vol. 97, núm. 3, p. 591-612.

Palabras clave: migración china; familismo; transnacionalismo; localismo; mujeres inmigrantes; maternidad; mujeres trabajadoras.

613-640 GUALDA, Estrella (Universidad de Huelva)

Migración circular en tiempos de crisis. Mujeres de Europa del Este y africanas en la agricultura de Huelva. Papers, 2012, vol. 97, núm. 3, p. 613-640.

Palabras clave: inmigración; mujer; europeas del este; africanas; marroquíes; contratos en origen; crisis económica; agricultura; migración circular; Huelva (España).

641-660 Villares VARELA, María (International Migration Institute)

¿Gracias al negocio o a pesar del negocio? La intersección entre familia y empresa para los emprendedores inmigrantes en Galicia. Papers, 2012, vol. 97, núm. 3, p. 641-660.

Palabras clave: empresas familiares; autoempleo; inmigración; migración de retorno; mujeres trabajadoras; España; Latinoamérica.

661-684 PARella Rubio, Sònia (Universitat Autònoma de Barcelona)

Familia transnacional y redefinición de los roles de género. El caso de la migración boliviana en España. Papers, 2012, vol. 97, núm. 3, p. 661-684.

Palabras clave: migraciones; transnacionalismo; división sexual del trabajo; Bolivia.

685-707 Roca I Girona, Jordi; Soronellas Masdeu, Montserrrat; BodoQUE PUERTA, Yolanda (Universitat Rovira i Virgili)

Migraciones por amor: diversidad y complejidad de las migraciones de mujeres. Papers, 2012, vol. 97, núm. 3, p. 685-707.

Palabras clave: migraciones internacionales; migraciones femeninas; género; familia; matrimonios mixtos. 
Ressenyes

709-711 GlaESER, Edward. El triunfo de las ciudades: Cómo nuestra mejor creación nos hace más ricos, más inteligentes, más ecológicos, más sanos y más felices (Christian Oltra).

712-714 Beneyto, Pere J. Reivindicación del sindicalismo. (Enric Sanchis). 
